\title{
PENGEMBANGAN VIDEO TUTORIAL SISTEM INFORMASI KELUARGA UNTUK PENINGKATAN KOMPETENSI TEKNIS PENYULUH KELUARGA BERENCANA
}

\section{Development of Tutorial Video on Family Information System for Technical Competence Improvement of Planned Family Instructors}

\author{
Susanto, Sri Sumarni, dan Fuad Abd. Rachman \\ Perwakilan Badan Kependudukan dan Keluarga Berencana Nasional Provinsi Lampung \\ Jl. Abdi Negara No.03, Kel. Gulak Galik, Telukbetung Utara, Bandar Lampung, Indonesia \\ mistersusanto@gmail.com; yik59unsri@yahoo.co.id; \\ fuad.abdrachman@yahoo.co.id
}

\author{
Diterima: \\ 06 Mei 2019, \\ Direvisi: \\ 11 Mei 2019, \\ Disetujui: \\ 15 Juni 2020
}

\begin{abstract}
ABSTRAK: Kebutuhan akan suatu media pembelajaran yang menarik dan efektif bagi Penyuluh Keluarga Berencana menuntut pengembangan media video tutorial yang valid, praktis, dan efektif. Penelitian ini bertujuan untuk menjawab kebutuhan tersebut, yaitu bagaimana menghasilkan video tutorial Sistem Informasi Keluarga yang valid, praktis, dan efektif. Penelitian ini dilakukan dengan menggunakan model pengembangan Alessi dan Trollip yang terdiri dari tiga tahapan, yaitu perencanaan, desain, dan pengembangan. Teknik pengumpulan data menggunakan wawancara, angket, observasi, dan tes. Validitas video tutorial dilakukan dengan uji alpa oleh dua orang ahli untuk masing-masing aspek (materi, media, dan desain pembelajaran). Uji validasi materi menghasilkan nilai 92,8 dan 100,0. Uji validasi media menghasilkan nilai 94,12 dan 100,0. Uji validasi desain mendapatkan nilai 83,33 dan 100,0. Dari nilai-nilai uji tersebut, dapat diartikan bahwa setelah dilakukan revisi produk, seluruh aspek dinyatakan sangat valid. Kepraktisan video tutorial diuji melalui uji beta dan diperoleh rerata nilai sebesar 80,67, yang berarti bahwa video tutorial ini termasuk kategori praktis. Efektifitas video tutorial terhadap hasil belajar diuji melalui uji lapangan (field test) pada kelas pelatihan di mana diperoleh nilai rerata pre-test 47,53 dan post-test 81,70. Peningkatan hasil belajar sebesar 34,18 dengan $N_{\text {gain }}$ skor sebesar 0,7 termasuk kategori tinggi. Dari hasil tes praktik, diperoleh rerata nilai 83,23, yang termasuk kategori baik. Dengan demikian, video tutorial sistem informasi keluarga yang dikembangkan dalam penelitian ini telah valid, praktis, dan memiliki efektifitas terhadap hasil belajar Penyuluh Keluarga Berencana.
\end{abstract}

Kata Kunci: Penelitian pengembangan; video tutorial sistem informasi keluarga; pelatihan.

ABSTRACT: The need for interesting and effective learning media for Planned Family Instructors requires the development of valid, practical, and effective tutorial video media. The objective of this research is to answer the challenge, i.e. how to produce a valid, practical, and effective Planned Family Information System tutorial video. This research is a development research applying Alessi and Trollip development 
model, consisting of three stages, namely: planning, designing, and development. Data are procured through interviews, questionnaires, observation, and tests. The validity of the tutorial video is tested by using alpa test by two experts for each aspect (material, media, and learning design). Material validity test results in the scores of 92.8 and 100.0. Media validation test indicates the scores of 94.2 and 100.0. The design validation test shows the scores of 83.33 and 100.0. Based on the scores, it can be interpreted - after the product is revised - that all aspects are very valid. The practicality of the tutorial video is tested by using beta test, and the average score is 80,67 , which means that this tutorial video is categorized practical. The effectiveness of this tutorial video towards the learning outcomes is tested through field test in the training class, where the average pre-test score is 47,53 and the average post-test score is 81,70 . An increase in learning outcomes of 34.17 with the $N_{\text {gain }}$ score of 0.7 is categorized as high category. Based on the practicality test, the average score is 83,23 , which is categorized in good category. Therefore, this Planned Family Information System tutorial video is valid, practical, and effective on the learning outcomes of Planned Family Instructors.

Keywords: development research; family information system tutorial video; training.

\section{PENDAHULUAN}

Perkembangan kependudukan dan pembangunan keluarga menjadi satu bagian yang tidak terpisahkan dari agenda pembangunan nasional. Penduduk harus menjadi titik sentral dalam pembangunan berkelanjutan di Indonesia. Selain itu, hal ini merupakan upaya meningkatkan dan menyiapkan generasi yang berkualitas sebagai modal pembangunan dalam rangka mewujudkan Agenda Pembangunan Nasional (Nawa Cita), terutama pada Cita ke-5 (lima) yaitu "Meningkatkan Kualitas Hidup Manusia Indonesia melalui Pembangunan Bidang Pengendalian Penduduk dan Keluarga Berencana" (BKKBN, 2016). Pengendalian penduduk dan Keluarga Berencana (KB) merupakan program prioritas pemerintah dari sisi pengendalian kuantitas dan kualitas penduduk. Kuantitas penduduk meliputi perubahan jumlah, struktur, komposisi, dan persebaran penduduk yang seimbang, sedangkan kualitas penduduk meliputi kontribusinya terhadap upaya mewujudkan norma keluarga kecil, bahagia, dan sejahtera (BKKBN, 2015).
Peningkatan kualitas Penyuluh Keluarga Berencana, yang selanjutnya disebut Penyuluh KB, merupakan salah satu upaya dalam mendukung percepatan tercapaiannya tujuan Program Keluarga Berencana (Kurniawan, Pratomo, dan Bachtiar, 2010). Peningkatan kemampuan Penyuluh KB dilakukan secara berkelanjutan melalui pengembangan potensi SDM (Azmy, 2015). Salah satu upaya yang dilakukan adalah optimalisasi pelaksanaan pendidikan dan pelatihan (diklat) bagi Penyuluh KB melalui Bidang Pelatihan dan Pengembangan (Latbang) Perwakilan BKKBN Provinsi Sumatera Selatan. Secara nasional, jumlah Penyuluh KB sebanyak 15.352 orang dengan rasio 1:5. Provinsi Sumatera Selatan memiliki 476 orang Penyuluh KB yang tersebar di 17 kabupaten/kota dengan rasio 1:5, artinya, satu penyuluh membina 5 (lima) desa/kelurahan (DITBINLAP, 2017). Untuk menjadi Penyuluh KB profesional dan kompeten, Penyuluh KB harus tersertifikasi. Peningkatan kapasitas Penyuluh KB dapat dilakukan melalui Latihan Dasar Umum (LDU), Pelatihan Refreshing, Pelatihan Teknis, Orientasi, Bimbingan Teknis, 
Pendidikan dan Pelatihan Penjejangan, Pendidikan S1, S2, S3, On Job Training, Elearning, dan Pembelajaran Jarak Jauh (Basri dan Rusdiana, 2015).

Penyuluh KB sebagai tenaga lapangan memiliki peran strategis demi tercapainya tujuan program Keluarga Berencana (KB). Oleh karena itu, Penyuluh KB harus profesional dan kompeten. Salah satu kompetensi yang harus dimiliki adalah kompetensi teknis (Kemenpan, 2018). Kompetensi teknis Penyuluh KB merupakan kemampuan kerja setiap Aparatur Sipil Negara (ASN) yang mencakup aspek pengetahuan, keterampilan, dan sikap kerja yang mutlak diperlukan dalam melaksanakan tugas-tugas jabatannya (BKKBN, 2017).

Salah satu kompetensi teknis yang harus dimiliki oleh Penyuluh KB adalah Pendataan Keluarga yang menghasilkan Basis Data Keluarga Indonesia (BDKI). Saat ini, BDKI sudah berbasis Teknologi Informasi dan Komunikasi (TIK) dalam bentuk aplikasi Sistem Informasi Keluarga (SIGA). Dalam kurikulum pendidikan dan pelatihan Perwakilan BKKBN Provinsi Sumatera Selatan, SIGA berbasis TIK menjadi salah satu kegiatan diklat teknis dalam meningkatkan kompetensi Penyuluh KB. Pelaksanaan diklat SIGA selama ini berlangsung 4 (empat) hari, diikuti 34 orang Penyuluh KB utusan dari 17 Kabupaten dan kota se-Sumatera Selatan. Materi utama yang disajikan oleh widyaiswara maupun fasilitator adalah definisi operasional SIGA, kebijakan dan strategi SIGA, perkembangan program KKBPK, mekanisme dan tata cara PBDKI, aplikasi manajemen wilayah, teknik pengumpulan data keluarga, PBDKI online dan offline, analisis data, pemutakhiran peta keluarga. Materi penunjang di antaranya sikap positif tim SIGA, rencana tindak lanjut, pretest dan post-test.

Metode yang digunakan dalam diklat SIGA adalah ceramah, tanya jawab, diskusi, demonstrasi, dan praktik lapangan dan praktik dalam kelas. Media yang digunakan dalam diklat adalah tayangan power point, flipchart, LCD proyektor, handout, dan lembar kerja. Metode pembelajaran yang digunakan adalah pembelajaran orang dewasa, sehingga hasil yang dicapai sesuai dengan tujuan diklat (Daryanto dan Tarno, 2017). Diharapkan peserta dapat memahami konsep pemutakhiran basis data keluarga Indonesia (PBDKI) secara online di wilayah binaannya masing-masing dan dapat mentransfer pengetahuannya dengan tim kerja di lapangan. Kenyataan yang terjadi pada saat melakukan pemutakhiran data melalui aplikasi SIGA, peserta sering kali lupa langkahlangkah yang harus dilakukan berdasarkan indikator yang telah ditetapkan. Oleh karena itu, fasilitator harus menyampaikan atau menampilkan kembali langkah-langkah pemutakhiran data tersebut melalui proyektor. Kejadian ini dialami sebagian besar peserta pelatihan, sehingga fasilitator harus memandu satu persatu peserta supaya tidak terjadi kesalahan dalam melakukan pemutakhiran data melalui aplikasi SIGA. Kondisi ini kurang efektif karena pembelajaran membutuhkan waktu dan tenaga lebih banyak, sedangkan alokasi waktu yang disediakan terbatas.

Berdasarkan identifikasi karakteristik Penyuluh KB melalui studi pendahuluan melalui dokumentasi yang peneliti lakukan pada 15 Februari 2018, diperoleh data awal bahwa Penyuluh KB saat ini memiliki pangkat, usia, dan disiplin ilmu yang variatif. Latar belakang pendidikan Penyuluh KB untuk pendidikan S2 sebesar 1,6\%, S1 sebesar 43,4\%, DIV sebesar 0,2\%, DIII sebesar 10,8\%, SLTA sebesar 42,9\%, dan < SLTA sebesar 1,2\%. Untuk komposisi usia Penyuluh $\mathrm{KB}$, jika dikelompokkan berdasarkan usia muda (20-45 tahun) sebesar 5\%, usia tengah (46-58 tahun) sebesar 30\%, dan usia tua ( $>58$ tahun) sebesar $65 \%$.

Selanjutnya, berdasarkan analisis hasil sertifikasi Penyuluh KB Tahun 2017, dilihat dari keterangan kompetensi per unit khususnya pada kompetensi teknis pendataan keluarga, masih banyak Penyuluh KB yang memerlukan pengembangan lebih lanjut. Analisis hasil sertifikasi Penyuluh KB Perwakilan BKKBN Provinsi Sumatera Selatan tahun 2017 selengkapnya dapat dilihat pada Tabel 1 berikut. 
Tabel.1: Hasil Sertifikasi Penyuluh KB

Unit Kompetensi Teknis Pendataan Keluarga Tahun 2017

\begin{tabular}{llll}
\hline Kategori & $\begin{array}{l}\text { Diatas } \\
\text { Standar }\end{array}$ & $\begin{array}{l}\text { Sesuai } \\
\text { Standar }\end{array}$ & $\begin{array}{l}\text { Pengem- } \\
\text { bangan } \\
\text { Lebih Lanjut }\end{array}$ \\
\hline $\begin{array}{l}\text { Penyuluh } 10 \text { orang } \\
\text { KB }\end{array}$ & 143 orang & 323 orang \\
Persen (\%) 2,10 & 30,04 & 67.86 \\
\hline
\end{tabular}

Sumber: Ditbinlap BKKBN, 2017

Dilihat dari Tabel 1 mengenai hasil sertifikasi tersebut, dari total jumlah Penyuluh KB sebanyak 476 orang di Sumatera Selatan, masih banyak Penyuluh KB yang masih memerlukan pengembangan lebih lanjut, khususnya pada unit kompetensi teknis pendataan keluarga, yaitu sebanyak 323 orang $(67,86 \%)$. Sebanyak 143 orang $(30,04 \%)$ masuk kategori sesuai standard. Sebanyak 10 orang $(2,10 \%)$ memiliki kemampuan di atas standar.

Berdasarkan hasil observasi dan analisis data hasil sertifikasi Penyuluh KB tahun 2017 di atas, dapat disimpulkan bahwa Penyuluh KB memerlukan suatu media pembelajaran yang lebih efektif dan menarik serta dapat menyajikan langkah-langkah PBDKI melalui aplikasi SIGA. Melalui media pembelajaran yang dirancang seperti tampilan aplikasi SIGA, Penyuluh KB lebih mudah memahami konsep dan langkah-langkah dalam mengoperasikan aplikasi SIGA. Pengulangan-pengulangan yang dilakukan peserta dapat memperdalam konsep materi yang sedang dipelajari dan dapat meningkatkan hasil belajarnya. Adapun media yang memiliki kualifikasi tersebut adalah video tutorial. Pembelajaran melalui video tutorial mudah dilakukan, memiliki desain yang menarik, pengenalan materi dasar yang disajikan melalui media video pembelajaran memberi wawasan peserta pelatihan sebelum memasuki inti materi pelajaran (Fahrurozi, 2017). Melalui video tutorial, materi dapat disajikan seperti tampilan yang terdapat pada aplikasi SIGA, dengan disertai narasi suara yang menjelaskan setiap langkah yang harus dilakukan oleh penggunanya (Riki Rahmad, 2018).
Terdapat banyak media baik cetak, elektronik, ataupun digital yang dapat digunakan dalam meningkatkan kualitas dan produktivitas pembelajaran diklat (Haryanto, 2015). Berdasarkan hasil penelitian DeVaney (2009) di USA dengan judul "Impact of Video Tutorial in an Online Educational Statistic Course", diketahui bahwa video tutorial menumbuhkan persepsi positif penggunanya, sehingga efektif dalam meningkatkan kinerja akademis. Senada dengan Maiyena dan Haris (2017), dalam penelitian yang berjudul "Praktikalitas Video Tutorial pada Mata Kuliah Eksperimen Fisika untuk Meningkatkan Keterampilan Proses Sains Mahapeserta" diketahui bahwa video tutorial sangat praktis digunakan dalam kegiatan pembelajaran, karena dapat diputar kembali sehingga diperoleh pemahaman yang mendalam.

Menurut Miarso (2015), dalam perspektif teknologi pendidikan, pembelajaran merupakan proses peningkatan mutu kemampuan seseorang melalui sebuah lembaga pendidikan dalam organisasi atau profesi sebagai peningkatan kinerja. Belajar merupakan perubahan dalam kepribadian, yang dimanifestasikan sebagai pola-pola respons yang baru yang berbentuk keterampilan, sikap, kebiasaan, pengetahuan dan kecakapan (Suyono dan Haryanto, 2016). Untuk memperoleh hasil pembelajaran yang optimal, perlu diidentifikasi hal-hal yang mempengaruhi produktivitas pembelajaran, di antaranya adalah metode belajar, sumber belajar, gaya belajar, dan media pembelajaran (Munir, 2017).

Menurut Ghufron dan Rini Risnawati (2014), terdapat tiga gaya belajar, yaitu: visual, audio, kinestetik, atau gabungan dari ketiganya. Gaya belajar peserta pelatihan juga perlu menjadi salah satu pertimbangan pendidik dalam menentukan metode pembelajaran yang akan digunakan, sehingga gaya belajar akan difasilitasi dan diakomodasi (Marpaung, 2014). Menurut Levie dan Levie dalam Zainiyati (2017), belajar melalui stimulus visual dan verbal dapat berdampak positif terhadap tugas-tugas belajar seperti mengingat, mengenali, dan mengingat kembali, dan menghubungkan fakta dan konsep. Menurut penelitian Baugh, kurang 
lebih $90 \%$ hasil belajar seseorang diperoleh melalui indra pandang, dan hanya sekitar 5\% melalui indra lainnya. Sementara itu, Dale menyatakan bahwa $75 \%$ hasil belajar diperoleh melalui indra pandang, 13\% indra dengar, dan $12 \%$ indra lainnya (Zainiyati, 2017).

Seorang pendidik yang berinteraksi dengan peserta pelatihannya dalam proses pembelajaran mengalami perubahan pesan yang disampaikan. Sebagai akibatnya adalah bahwa kealamiahan proses pembelajaran di kelas seringkali berubah menjadi kurang efektif (Suprijanto, 2012). Hambatanhambatan tersebut adalah verbalisme, kebingungan acuan (reference confusion), lamunan, ketidaknampakan, ketidakminatan, dan ketidaknyamanan psikologis (Abdulhak dan Darmawan, 2015). Untuk menghindari hal tersebut, pendidik dapat menyusun strategi pembelajaran dengan memanfaatkan media dan sumber belajar (Rusman, 2013).

Berdasarkan kerucut pengalamannya (cone of experience), Dale dalam Sanjaya (2016) menyatakan bahwa pengalaman belajar yang diperoleh peserta pelatihan secara langsung sangat bermanfaat. Melalui media pembelajaran, hal yang bersifat abstrak dapat menjadi lebih konkret. Hasil penelitian Dwyer dalam Kiswieantoro (2017), meyebutkan bahwa setelah lebih dari tiga hari pada umumnya manusia dapat mengingat pesan yang disampaikan melalui tulisan sebesar $10 \%$, pesan audio $20 \%$, visual $30 \%$, audio visual 50\%, dan apabila ditambah melakukan akan tercapai 80\%.

Menurut Bretz dalam Prawiradilaga (2014), terdapat 3 (tiga) fungsi media pembelajaran yaitu sebagai sistem, subsistem, dan pengayaan. Sebagai sistem, media dikembangkan dengan komponen lengkap, layaknya suatu sistem pembelajaran. Biasanya media tersebut dimanfaatkan dalam belajar mandiri. Media sebagai subsistem digunakan sebagai bagian dari pembelajaran. Penggunaannya sangat tergantung atas kompetensi pendidik. Media untuk pengayaan adalah media yang disiapkan sebagai suatu pilihan bagi peserta pelatihan agar lebih mampu menguasai materi pembelajaran yang telah dirumuskan dalam tujuan pembelajaran.
Selanjutnya, Levie dan Lentz mengemukakan bahwa media pembelajaran khususnya media visual memiliki empat fungsi, yaitu: fungsi atensi, afektif, kognitif, dan kompensatoris. Fungsi atensi media visual merupakan inti, yaitu menarik dan mengarahkan perhatian peserta didik untuk berkonsentrasi terhadap materi yang disampaikan (Arsyad, 2015). Menurut Lestari (2014), video merupakan salah satu jenis media audio-visual dan dapat menggambarkan suatu objek yang bergerak bersama-sama dengan suara alamiah atau suara yang sesuai.

Hasil penelitian Martin (2016) di Selandia Baru dengan judul "Tutorial Video by Senior Undergraduate Electrical Engineering Student" membuktikan bahwa pembelajaran dengan menggunakan video tutorial membuat peserta dapat memilih materi pembelajaran mereka sesuai kebutuhan masing-masing dan juga membuat konsep dan pengetahuan yang sulit, dapat disajikan dengan mudah. Namun demikian, masih perlu dikembangkan materi tambahan sebagai pengayaan terhadap konsep dan pengetahuan untuk meningkatkan prestasi belajar peserta.

Hasil penelitian Meij (2014) di Belanda yang berjudul "Developing and Testing a Video Tutorial for Software Training" menunjukkan bahwa materi yang dipelajari dan disampaikan melalui video tutorial memberikan mood positif bagi peserta pada saat pembelajaran berlangsung. Selain itu, video tutorial sangat efektif digunakan dalam pembelajaran karena didukung desain dan tampilan yang menarik. Berdasarkan hasil penelitian tersebut, dapat diketahui bahwa video tutorial sebagai media pembelajaran sangat tepat dalam meningkatkan motivasi, pengetahuan dan keterampilan, serta perlu pengembangan lebih lanjut.

Berdasarkan studi pendahuluan yang dilakukan peneliti melalui wawancara kepada Helmi Wahyudianto, SE. selaku Penyuluh KB pada tanggal 21 Februari 2018, diperoleh informasi bahwa proses kegiatan pembelajaran pada Bidang Latbang Perwakilan BKKBN Provinsi Sumatera Selatan telah memanfaatkan media dalam pembelajaran, di antaranya, handout, slide power point, flip chart dan alat peraga. Metode 
pembelajaran yang digunakan adalah ceramah, tanya jawab, diskusi, role play, praktik lapangan, dan praktik mandiri di dalam kelas. Pemanfaatan media dan metode pembelajaran yang digunakan selalu sama sehingga pembelajaran berlangsung monoton dan cenderung kurang menarik. Peserta pelatihan (Penyuluh KB) menjadi kurang termotivasi dan kurang aktif dalam proses pembelajaran karena muatan materi yang disampaikan hampir sama sehingga mudah dilupakan setelah pembelajaran selesai. Pada saat Penyuluh KB melakukan praktik PBDKI melalui aplikasi SIGA, mereka selalu mengalami kesulitan sehingga memerlukan waktu yang relatif lama, meskipun sudah disediakan panduan berupa handout.

Pada tanggal 22 Februari 2018, peneliti melakukan wawancara kepada Lausa Isaberna, S.Sos. selaku widyaiswara muda di Diklat Perwakilan BKKBN Provinsi Sumatera Selatan, dan diperoleh informasi bahwa dukungan anggaran dalam rangka pengadaan media pembelajaran terbatas sehingga ketersediaan media pembelajaran kurang lengkap dalam mengakomodir kebutuhan belajar peserta. Berdasarkan observasi yang dilakukan peneliti pada tanggal 26 Februari 2018 di Diklat Perwakilan BKKBN Provinsi Sematera Selatan, diperoleh informasi bahwa media pembelajaran yang digunakan yaitu handout, slide power point, flipchart dan alat peraga. Metode pembelajaran yang digunakan oleh widyaiswara, instruktur, dan fasilitator adalah ceramah, tanya-jawab, diskusi, role play, praktik lapangan dan praktik mandiri di dalam kelas.

Pelaksanaan diklat teknis yang menekankan pemahaman konsep materi dan pendekatan softskill Penyuluh KB memerlukan media pembelajaran untuk memudahkan pemahaman konsep materi yang dipelajari dan berhasil meningkatkan kompetensinya. Oleh karena itu, peneliti perlu mengembangkan dan melakukan penelitian pengembangan yang berjudul "Pengembangan Video Tutorial Sistem Informasi Keluarga pada Pendidikan dan Pelatihan Perwakilan Badan Kependudukan dan Keluarga Berencana Nasional Provinsi Sumatera Selatan".

\section{METODA}

Jenis penelitian ini adalah penelitian pengembangan (Development Research) dengan menggunakan teknik analisis data deskriptif kualitatif dan kuantitatif (Setyosari, 2016). Penelitian ini dilakukan pada bulan Desember 2018 di Diklat Perwakilan BKKBN Provinsi Sumatera Selatan dengan penyuluh KB sebanyak 34 orang.

Tujuan dari penelitian ini adalah mengembangkan media pembelajaran video tutorial Sistem Informasi Keluarga pada diklat perwakilan BKKBN Provinsi Sumatera Selatan. Model pengembangan yang digunakan dalam penelitian ini adalah model Alessi dan Trollip (Tegeh, Jampel, dan Pudjawan, 2014). Adapun model pengembangan Alessi dan Trollip (2001) terdiri tiga tahap yaitu perencanaan, desain, dan pengembangan.

Tahap perencanaan merupakan tahap awal dalam melakukan penelitian pengembangan model Allesi dan Trollip. Pada tahap perencanaan, dilakukan identifikasi kebutuhan peserta pelatihan dan analisis kebutuhan. Hal ini bertujuan untuk mengetahui apakah media video tutorial yang dikembangkan sudah sesuai dengan kebutuhan peserta pelatihan. Analisis kurikulum diperlukan terkait dengan muatan isi yang akan disajikan dalam video tutorial.

Identifikasi karakteristik peserta pelatihan melalui studi dokumentasi bertujuan untuk mengetahui kemampuan yang dimiliki peserta pelatihan untuk dapat mengikuti pembelajaran. Penyiapan materi pokok yang akan ditampilkan di dalam video tutorial meliputi gambar, video, dan animasi disesuaikan dengan silabus agar proses pembelajaran maupun materi pembelajaran sesuai dengan kebutuhan peserta pelatihan. Selanjutnya, menentukan dan mengumpulkan sumber daya yang mungkin diperlukan selama pembuatan video tutorial. Menurut Pribadi (2017), terdapat tiga jenis bahan dalam pembuatan video tutorial, yaitu: (1) sumber daya yang berkaitan dengan materi; (2) bahan terkait dengan pengembangan instruksional dan proses pengajaran; dan (3) materi yang berhubungan dengan 
pengembangan produk. Melakukan diskusi mengenai ide awal perlu dilakukan dalam menentukan materi yang akan digunakan.

Kegiatan ini dilakukan dalam bentuk diskusi dengan widyaiswara dan dosen pembimbing berkaitan dengan konten materi yang direncanakan dalam pembuatan video tutorial. Selanjutnya adalah menentukan tampilan pada video tutorial. Prototipe adalah cara yang tepat untuk memastikan tampilan dalam produk video tutorial sesuai dengan tujuan (Nurseto, 2011). Kemudian, menentukan dan mengumpulkan sumbersumber berupa gambar animasi, dan suara untuk bahan pembuatan video tutorial.

Tahap desain merupakan perancangan awal video tutorial. Pada tahap ini, peneliti mengembangkan konsep pembelajaran, membuat flowchart, storyboard, dan mempersiapkan prototipe perangkat lunak yang digunakan dalam penelitian ini. Perangkat lunak yang diperlukan di antaranya adalah aplikasi Camtasia Studio, Cool Edit, Adobe After Effect, Adobe Flash, Sparkol Video Scribe dan beberapa aplikasi lain yang mendukung sehingga dihasilkan video tutorial yang valid, praktis, dan efektif (Suryani, Setiawan, dan Putria, 2018).

Tahap pengembangan, peneliti menyiapkan petunjuk penggunaan media pembelajaran video tutorial, menyiapkan materi-materi pendukung, membuat produk, melakukan uji alpa untuk mengetahui kevalidan produk, melakukan uji beta untuk mengetahui keperaktisan produk, melakukan revisi akhir, dan selanjutnya langkah terakhir yaitu melakukan uji coba produk berupa media pembelajaran menggunakan video pada pelatihan sebenarnya untuk mengetahui efektifitas terhadap hasil belajar penyuluh KB.

\section{Teknik Pengumpulan Data}

Pengumpulan data dalam penelitian ini menggunakan beberapa cara, yaitu: observasi, dokumentasi, dan wawancara yang dilakukan selama studi pendahuluan, serta validasi ahli, angket kepraktisan, dan tes hasil belajar yang digunakan untuk mengetahui efektifitas media yang dikembangkan. Instrumen yang digunakan dalam validasi ahli dan angket kepraktisan adalah dari Anidi
(2017), Arsyad (2015), dan Kemendikbud, 2016) yang dimodifikasi oleh peneliti disesuaikan dengan kebutuhan penilaian terhadap media yang digunakan dalam penelitian ini.

\section{Teknik Analisis Data}

Yusus, dalam Anidi (2017), menyatakan bahwa analisis data kualitatif merupakan proses mereviu dan memeriksa data, serta mensintesis dan mengintepretasikan data yang terkumpul sehingga menggambarkan fenomena dan situasi yang diteliti.

Untuk analisis data observasi awal pada tahapan observasi, peneliti melakukan pengamatan untuk mengetahui masalah pada penyelenggaraan diklat yang dilaksanakan. Untuk analisis dokumentasi, data yang diperoleh dari studi pendahuluan atau data sekunder direduksi, mendisplay data berupa teks yang bersifat naratif (Arikunto, 2014). Dokumentasi yang digunakan dalam penelitian ini meliputi laporan kegiatan, baik yang tercetak maupun yang bersifat online, peraturan yang dikeluarkan oleh BKKBN pusat dan provinsi, alokasi jadwal kegiatan, kurikulum pelatihan, dan dokumen lain yang menunjang dalam penelitian ini.

Analisis wawancara dilakukan pada tahap studi pendahuluan untuk mengetahui permasalahan utama terkait dengan proses pembelajaran diklat teknis yang telah dilaksanakan selama ini. Wawancara dilakukan kepada Penyuluh KB yang menjadi peserta pelatihan dan widyaiswara pada diklat Perwakilan BKKBN Provinsi Sumatera Selatan.

Analisis validasi ahli dilakukan untuk mengetahui apakah desain dan media tersebut valid, praktis, dan efektif atau sebaliknya (van den Akker, 1999). Para ahli memberikan penilaian terhadap produk desain dan media pembelajaran tersebut sehingga penggunaan media pembelajaran terpenuhi validitasnya. Untuk mengetahui valid atau tidaknya suatu materi, desain pembelajaran, dan media pembelajaran yang telah dikembangkan, peneliti melakukan penghitungan dengan menggunakan rumus berikut. 
validasi ahli $=\frac{\text { jumlah skor yang diperoleh }}{\text { skor maksimal }} \times 100 \%$

Berdasarkan hasil perhitungan rumus di atas, perolehan nilai dari validasi ahli dikonversi menjadi beberapa kategori seperti pada Tabel 2.

Tabel 2. Kategori Validasi Ahli

\begin{tabular}{ll}
\hline Nilai & Kategori \\
\hline $81-100$ & Sangat valid \\
\hline $51-80$ & Valid \\
\hline $26-50$ & Cukup Valid \\
\hline$<25$ & Tidak Valid \\
\hline
\end{tabular}

Riduwan (2015)

Analisis angket subjek penelitian dilakukan untuk melakukan penilaian terhadap kepraktisan dari segi pengguna atau pembelajar yang dapat dilihat dari hasil angket yang diberikan kepada Penyuluh KB sebagai subjek penelitian. Angket menggunakan skala Likert dengan rentang empat pilihan yaitu sangat baik (SB), baik (B), cukup baik (CB), tidak baik (TB), dan sangat tidak baik (STB). Adapun penilaian yang diberikan terhadap butir soal pada angket tampak seperti pada Tabel 3.

Tabel 3. Nilai Angket dengan Skala Likert

\begin{tabular}{lccccc}
\hline Kategori & SB & B & CB & TB & STB \\
\hline $\begin{array}{l}\text { Pertanyaan } \\
\text { praktikalitas }\end{array}$ & 5 & 4 & 3 & 2 & 1 \\
\hline
\end{tabular}

(Sugiyono, 2017)

Setelah angket diperoleh kembali dari subjek penelitian, dilakukan analisis, dan data dikonversikan menjadi nilai persentase. Hal ini diperlukan untuk menilai sejauh mana kepraktisan media tersebut terhadap kegiatan pembelajaran yang dilakukan oleh pembelajar. Rumus untuk menghitung nilai kepraktisan media pembelajaran terhadap subjek peneilitian adalah sebagai berikut.

Kepraktisan $=\frac{\text { jumlah skor setiap item pertanyaan }}{\text { jumlah skor ideal seluruh item }} \times 100 \%$
Kemudian nilai tersebut dikonversikan untuk menentukan penilaian peserta didik terhadap media yang telah dipersiapkan. Kriteria penilaian dapat dilihat dalam Tabel 4.

Tabel 4. Kriteria Kepraktisan Media Pembelajaran

\begin{tabular}{ll}
\hline Rerata & Kategori \\
\hline $4,21-5,00$ & Sangat praktis \\
\hline $3,41-4,20$ & Praktis \\
\hline $2,61-3,40$ & Cukup praktis \\
\hline $1,81-2,60$ & Kurang praktis \\
\hline $1,00-1,80$ & Tidak praktis \\
\hline
\end{tabular}

Sumber: Sudiyono dalam Anidi (2017)

Analisis hasil tes belajar dilakukan untuk mengetahui perubahan peserta sebelum dan setelah mengikuti pembelajaran dengan media pembelajaran yang telah dikembangkan. Penilaian awal dilakukan dengan memberikan pre-test dan setelah selesai mengikuti pembelajaran yang telah ditentukan, diberikan post-test untuk melihat perubahan dari peserta pelatihan.

Setelah dilakukan perhitungan nilai pretest dan post-test, selanjutnya adalah menghitung $\mathrm{N}_{\text {gain }}$ dengan rumus berikut.

$$
N_{\text {gain }}=\frac{\text { Skor pos test }- \text { Skor Pre test }}{\text { Skor Maksimal }- \text { Skor Pre test }}
$$

Setelah menghitung nilai $\mathrm{N}_{\text {gain }}$, kemudian di konversikan untuk mengetahui kategori hasil belajar dapat dilihat dari tabel 5 .

Tabel 5. Kriteria Perolehan $N_{\text {gain }}$

\begin{tabular}{ll}
\hline Kriteria Nilai $\mathbf{N}_{\text {gain }}$ & Kategori \\
\hline Jika $\mathrm{N}_{\text {gain }}$ e" 0,7 & Tinggi \\
\hline Jika $0,7>\mathrm{N}_{\text {gain }}$ e" 0,3 & Sedang \\
\hline Jika $\mathrm{N}_{\text {gain }}<0,3$ & Rendah \\
\hline
\end{tabular}

Sumber: Hake (1998)

\section{HASIL DAN PEMBAHASAN}

Pada tahap ini, peneliti menguraikan hasil dan pembahasan dari penelitian yang telah dilakukan dengan menggunakan video tutorial sistem informasi keluarga pada pendidikan dan pelatihan (diklat) Perwakilan BKKBN 
Provinsi Sumatera Selatan. Penelitian ini diharapkan menghasilkan video tutorial sistem informasi keluarga yang valid, praktis, dan efektif dengan menggunakan program Adobe Flash didukung oleh program Camtasia Studio 8.0, Cool Edit, Sparkol Video Scribe, Adobe Premiere dan Adobe After Effect. Pada tahap metodologi penelitian, peneliti menggunakan model pengembangan Allessi dan Trollip yang merupakan model pengembangan yang menghasilkan produk noncetak. Tahap model pengembangannya meliputi tahap perencanaan, desain, dan pengembangan.

Pada tahap perencanaan, peneliti telah melakukan analisis kebutuhan, analisis karakteristik peserta pelatihan yaitu Penyuluh $\mathrm{KB}$, analisis sarana dan prasarana, analisis media pembelajaran dan analisis kurikulum. Analisis kebutuhan, baik kebutuhan peserta pelatihan, widyaiswara, maupun kebutuhan lingkungan. Hasil analisis kebutuhan ini didapatkan melalui data dokumentasi, data hasil angket, dan data hasil wawancara.

Berdasarkan data tersebut, diperoleh fakta bahwa peserta pelatihan memiliki latar belakang yang heterogen, baik dari sisi pendidikan, golongan, dan usia. Kurangnya pemanfaatan sarana dan prasarana yang dapat menunjang kegiatan pembelajaran, pendidik dalam mengajar masih menggunakan media buku ajar, materi yang ditayangkan melui power point. Mata diklat Sistem Informasi Keluarga (SIGA) belum optimal, karena peserta pelatihan dituntut dapat menguasai konsep dan mempraktikan proses pendataan dan pemutakhiran data keluarga.

Peserta pelatihan dalam jangka waktu relatif pendek harus menguasai materi yang disampaikan oleh widyaiswara atau fasilitator dan berbagai konsep abstrak yang sebagian tidak kontekstual. Peserta pelatihan cenderung cepat merasa bosan jika hanya mendengarkan. Peserta pelatihan mengalami kesulitan untuk memahami materi diklat dengan baik. Peserta pelatihan menjadi pasif dalam menerima materi materi diklat yang disampaikan oleh fasilitator. Kurangnya minat belajar dan kurangnya motivasi belajar berakibat pada hasil belajar yang kurang memuaskan.
Model pembelajaran yang digunakan fasilitator adalah metode ceramah berdasarkan teks dan materi yang ditayangkan melalui PowerPoint. Metode ini membuat peserta pelatihan hanya mendengarkan dan mencatat materi yang dijelaskan oleh fasilitator karena peserta tidak mengalami langsung dan tidak dapat belajar sesuai dengan kecepatan belajarnya.

Dari analisis karakteristik awal, diperoleh data bahwa peserta diklat rata-rata berusia 37 tahun, usia terendah 25 tahun, dan usia tertinggi 53 tahun. Jika dikelompokan berdasarkan kelompok usia, usia muda (2030 tahun) sebesar $14.71 \%$, usia tengah (3158 tahun) sebesar $85,29 \%$ dan usia tua ( $>58$ tahun) sebesar 0\%. Latar belakang pendidikan peserta pelatihan terdiri dari Strata 2 sebesar $11,76 \%$, Strata 1 sebesar 73,53\%, DIII sebesar $14,71 \%$ dengan berbagai disiplin ilmu. Pangkat dan golongan cukup variatif yaitu Pengatur Muda/II.a 5,88\%, Pengatur/II.c 2,94\%, Pengatur Tk.I/II.d 2,94\%, Penata Muda/III.a 35,29\%, Penata Muda Tk.I/III.b 29,41\%, Penata/III.c 11,76\% dan Penata Tk.I/ III.d 5,88\%. Berdasarkan hasil sertifikasi peserta tahun 2017, kategori di atas standar (DS) $11,76 \%$, sesuai standar (SS) $38,24 \%$, dan perlu tindak lanjut pengembangan (TL) $50,00 \%$. Jenis kelamin peserta, laki-laki sebanyak $29,41 \%$ dan perempuan $70,59 \%$, status perkawinan peserta $64,71 \%$ kawin, dan $35,29 \%$ belum kawin.

Dari analisis sarana dan prasarana yang dilakukan melalui observasi, diperoleh informasi bahwa di Diklat Perwakilan BKKBN Provinsi Sumatera Selatan memiliki ruang belajar yang representatif. Sudah tersedia LCD Poyektor, Sound system, laptop, dan jaringan internet (Wifi). Seluruh peserta pelatihan telah memiliki laptop dengan spesifikasi yang memadai.

Analisis media pembelajaran, yang diperoleh dari hasil observasi dan wawancara dengan teman sejawat, menunjukkan fakta bahwa penggunaan media dalam proses pembelajaran terutama media komputer kurang optimal. Hal ini disebabkan karena kurangnya penguasaan fasilitator/ widyaiswara dalam membuat media pembelajaran dan memanfaatkan media 
pembelajaran yang berbasis komputer.

Melalui analisis kurikulum, peneliti memilih diklat teknis sistem informasi keluarga berbasis teknologi informasi dengan mata diklat Pemutakhiran Basis Data Keluarga Indonesia (PBDKI) dikarenakan mata diklat tersebut merupakan kemampuan utama yang harus dikuasai penyuluh $\mathrm{KB}$, karena PBDKI sebagai acuan dalam menentukan sasaran prioritas Penyuluh KB dalam melayani masyarakat. Selain itu, diklat tersebut menuntun keterampilan penyuluh KB dalam mengoprasikan aplikasi SIGA sebagai tools yang telah disediakan BKKBN pusat.

Pada tahap desain, peneliti melakukan kegiatan pengembangan konsep awal video tutorial sistem informasi keluarga pada diklat teknis sistem informasi keluarga dengan mata diklat pemutakhiran basis data keluarga Indonesia.

Membuat konsep awal video tutorial yang akan dikembangkan sesuai dengan kebutuhan yang diperlukan dan karakteristik yang dimiliki peserta pelatihan. Mengembangkan topik-topik yang akan menjadi konten video tutorial sistem informasi keluarga yang hasilnya tergambar ada flowchart. Flowchart yang dibuat dimulai dari pembuka, isi, dan penutup. Membuat GBPM bertujuan untuk menentukan materi yang akan dibuat dalam storyboard. Membuat storyboard berdasarkan GBPM yang telah dibuat. Isi dalam storyboard terdiri atas menu petunjuk kompetensi, materi, latihan soal, dan profil. Selanjutnya adalah mengumpulkan isi media berupa teks, gambar, ataupun video. Kemudian dirancang menjadi sebuah media video tutorial sesuai dengan materi. Menentukan software Camtasia Studio 8, Adobe Flash professional CS6, Cool edit, Adobe Audition, Adobe Premiere, Adobe After Effect, dan Sparkol Video Scribe, sehingga dapat menghasilkan media yang menarik, mudah digunakan dan mudah dipahami.

Pada tahap pengembangan, peneliti menyiapkan teks, gambar, audio dan video terkait dengan materi dan pendukung materi yang akan dimuat di didalam video tutorial dilanjutkan dengan memproduksi protototipa video tutorial sistem informasi keluarga. Setelah melalui tahap perencanaan, desain, hingga dihasilkan prototipa video tutorial sistem informasi keluarga, selanjutnya dilakukan uji alpa, uji beta, dan uji lapangan (field test).

Uji alpa dilakukan untuk memperoleh validasi dari para ahli terhadap video tutorial yang dikembangkan peneliti, baik dari aspek materi, desain, maupun media. Pada tahap ini, peneliti meminta saran, masukan, dan komentar para ahli yang terdiri dari 2 (dua) ahli materi, 2 (dua) ahli desain, 2 (dua) ahli media terhadap video tutorial yang dikembangkan. Komentar dan saran yang diberikan selanjutnya dijadikan sebagai bahan perbaikan untuk merevisi video tutorial hingga dinyatakan valid atau layak untuk diujicobakan.

Validasi materi dilakukan oleh dua orang ahli materi dan diperoleh hasil sebesar 92,8 dan 100 , kategori sangat valid. Komentar ahli menyatakan bahwa dari aspek penyajian dan aspek bahasa sudah sesuai dan layak diujicobakan tanpa revisi.

Validasi media dilakukan oleh dua orang ahli media, dan diperoleh hasil 94,12 dan 100 kategori sangat valid. Validator pertama memberikan komentar dan saran agar bentuk huruf pada halaman utama lebih formal, kata pada lembar evaluasi diganti dengan lembar latihan soal dan tambahkan model (talent) pada halaman pembuka dan penutup di setiap video materi. Setelah peneliti melakukan revisi berdasarkan saran ahli media pertama, selanjutnya peneliti melakukan validasi dengan ahli media kedua dengan hasil bahwa video tutorial yang dikembangkan dinyatakan layak diujicobakan tanpa revisi.

Validasi ahli desain pembelajaran dilakukan oleh dua orang ahli desain pembelajaran, diperoleh hasil sebesar 83,33 dan 100 , kategori valid dan sangat valid. Validator pertama memberikan komentar dan saran bahwa perlu dibuatkan Hypothetical Learning Trajectory (HLT) untuk pembelajaran materi pemutakhiran basis data keluarga Indonesia. Selanjutnya, hasil validasi dengan ahli desain kedua diperoleh hasil bahwa video tutorial yang dikembangkan dinyatakan layak diujicobakan tanpa revisi. 


\section{Hasil Uji Beta}

Tahapan uji beta dilakukan pada 3 (tiga) orang penyuluh KB melalui kuesioner kepraktisan. Penilaian kuesioner kepraktisan penyuluh KB dinilai secara kuantitatif, selanjutnya rerata hasil penilaian penyuluh KB tersebut dikategorikan tingkat kepraktisannya. Berdasarkan hasil analisis kuesioner kepraktisan pada uji beta yang dilakukan kepada tiga orang penyuluh KB, menunjukkan bahwa ES dengan rerata sebesar 4,35 kategori sangat praktis, AJ dengan rerata sebesar 4,00 kategori praktis, dan AR dengan rata-rata sebesar 3,75 kategori praktis. Dengan demikian, rerata hasil keseluruhan penilaian kuesioner kepraktisan penyuluh KB terhadap media video tutorial diperoleh nilai sebesar 4,03 kategori praktis. Dengan demikian, media pembelajaran dengan menggunakan video tutorial sistem informasi keluarga pada pendidikan dan pelatihan layak di uji cobakan dalam penelitian.

\section{Hasil Pre-test}

Uji lapangan dilaksanakan oleh peneliti di Diklat Perwakilan BKKBN Provinsi Sumatera Selatan pada tanggal 11 Desember 2018 pada pelatihan Sistem Informasi Keluarga (SIGA) berbasis teknologi informasi bagi Penyuluh KB di ruang belajar diklat yang diikuti oleh 34 orang penyuluh KB selaku peserta pelatihan. Peneliti memberikan pre-test berupa soal pilihan ganda sebanyak 25 butir soal dengan waktu pengerjaan 45 menit. Data rekapitulasi pre-test peserta pelatihan dapat dilihat pada Tabel 6.

Tabel 6. Rekapitulasi Hasil Pre-test Peserta Pelatihan SIGA Berbasis TI

\begin{tabular}{llrl}
\hline $\begin{array}{l}\text { Interval } \\
\text { skor }\end{array}$ & $\begin{array}{l}\text { Jumlah } \\
\text { peserta }\end{array}$ & Kategori & Persentase \\
\hline $90-100$ & 0 peserta & $0 \%$ & Sangat Baik \\
$80-89$ & 0 peserta & $0 \%$ & Baik \\
$60-79$ & 6 peserta & $17,65 \%$ & Cukup \\
$50-59$ & 6 peserta & $17,65 \%$ & Kurang \\
$0-49$ & 22 peserta & $64,70 \%$ & Sangat kurang \\
\hline Jumlah & 34 Peserta & $\mathbf{1 0 0 \%}$ & \\
\hline Rerata & & $\mathbf{4 8 , 9}$ & Sangat kurang \\
\hline
\end{tabular}

\section{Hasil Post-test}

Post-test diberikan kepada peserta pelatihan setelah mengikuti pembelajaran dengan media yang dikembangkan. Pelaksanaan post-test menggunakan soal yang sama pada saat melaksanakan pre-test yaitu sebanyak 25 soal yang berkaitan dengan pelatihan Sistem Informasi Keluarga. Data hasil post-test dapat dilihat pada Tabel 7.

Tabel 7. Rekapitulasi Hasil Post-test

\begin{tabular}{lccl}
\hline $\begin{array}{l}\text { Interval } \\
\text { skor }\end{array}$ & $\begin{array}{c}\text { Jumlah } \\
\text { peserta }\end{array}$ & Kategori & Persentase \\
\hline $90-100$ & 3 peserta & $8,82 \%$ & Sangat Baik \\
$80-89$ & 19 peserta & $55,88 \%$ & Baik \\
$60-79$ & 12 peserta & $35,29 \%$ & Cukup \\
$50-59$ & 0 peserta & $0 \%$ & Kurang \\
$0-49$ & 0 peserta & $0 \%$ & Sangat kurang \\
\hline Jumlah & 34 Peserta & $\mathbf{1 0 0 \%}$ & \\
\hline
\end{tabular}

Berdasarkan data di atas, diketahui bahwa rata-rata nilai pre-test sebesar 47,53, sedangkan post-test sebesar 81,71. Nilai terendah pre-test sebesar 32,0 sedangkan terendah post-test 72,0 . Nilai tertinggi pre-test sebesar 74,0 sedangkan post-test 96,00 . Perbandingan nilai antara pre-test dan post-test selangkapnya dapat dilihat pada Gambar 1.

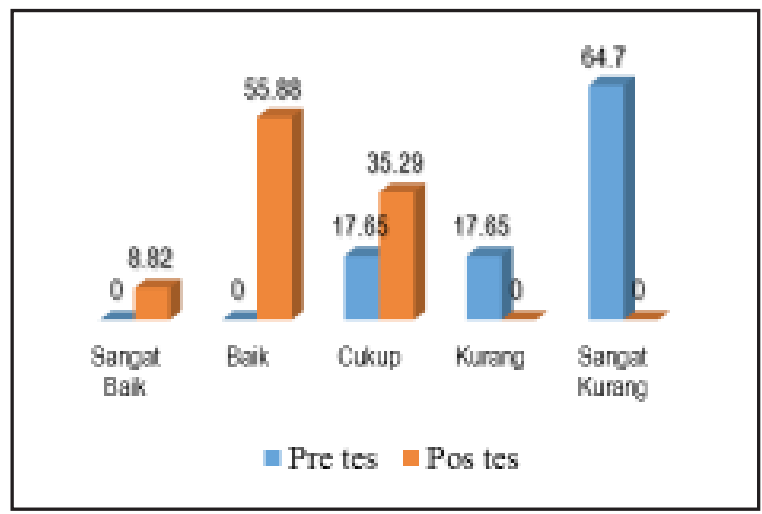

Gambar 1. Perbandingan Persentase antara Nilai pre-test dan post-test Peserta Pelatihan SIGA Berbasis TI dengan Video Tutorial

Untuk mengetahui pemahaman atau penguasaan konsep peserta pelatihan setelah pembelajaran, dapat dilihat dari peningkatan hasil belajar peserta. Dengan menggunakan rumus $N_{\text {gain }}$ (Hake, 1999), dari perhitungan pre-test dan post-test, nilai gain score 
diperoleh dengan menggunakan rumus:

$$
\mathrm{N}_{\text {gain }}=\frac{81,71-47,53}{100-47,53}
$$

Berdasarkan perhitungan di atas, didapat nilai $\mathrm{N}_{\text {gain }}=0,7$ yang termasuk kategori tinggi. Hal ini menunjukkan bahwa penggunaan media video tutorial sistem informasi keluarga memiliki dampak sangat baik terhadap hasil belajar peserta pelatihan.

Peningkatan nilai peserta diklat dari pretest ke post-test menunjukan bahwa media yang digunakan dapat membantu peserta diklat dalam meningkatkan kompetensi teknis. Penggunaan media ini dapat meningkatkan motivasi peserta pelatihan dan dapat menambah pemahaman terhadap mata diklat yang disajikan. Melalui video tutorial, peserta dapat belajar dengan kecepatan yang dimiliki dan dapat mengulang bagian-bagian yang kurang dipahami sesuai dengan kebutuhan. Secara keseluruhan, media yang dikembangkan dapat membantu peserta pelatihan dalam meningkatkan pemahaman konsep materi yang diberikan melalui media tersebut. Data di atas meunjukkan bahwa media video tutorial sistem informasi keluarga dinilai efektif dalam meningkatkan hasil belajar dan kompetensi peserta pelatihan.

\section{SIMPULAN DAN SARAN}

\section{Simpulan}

Berdasarkan hasil penelitian yang telah dilakukan mengenai Pengembangan Video Tutorial Sistem Informasi Keluarga pada Pendidikan dan Pelatihan (Diklat) Perwakilan BKKBN Provinsi Sumatera Selatan, dapat disimpulkan sebagai berikut.

Media video tutorial sistem informasi keluarga pada diklat Penyuluh KB telah teruji validitasnya setelah diuji melalui 3 aspek yaitu materi, media, dan desain pembelajaran. Berdasarkan ketiga kategori tersebut, media ini layak digunakan dengan beberapa revisi.

Media video tutorial sistem informasi keluarga pada diklat Penyuluh KB telah teruji praktikalitasnya. Hal ini telihat dari uji beta terhadap 3 (tiga) orang penyuluh KB dengan kualifikasi kemampuan di atas standar, sesuai standard, dan perlu pengembangan lebih lanjut. Melalui instrumen angket, diperoleh nilai dengan kategori praktis dan sangat praktis. Jadi, media video tutorial yang dikembangkan praktis dapat digunakan dalam pembelajaran.

Media video tutorial sistem informasi keluarga pada diklat Penyuluh KB memiliki efektifitas terhadap peningkatan kompetensi peserta. Hal ini terlihat dari peningkatan hasil belajar antara nilai pre-test dan post-test. Pada pre-test, nilai dominasi ada pada kategori sangat kurang, sedangkan pada post-test, nilai dominasi ada pada kategori baik. Hal ini juga terlihat pada skor $\mathrm{N}_{\text {gain }}$ yang ada pada kategori tinggi dan sedang.

\section{Saran}

Berdasarkan hasil penelitian yang dilakukan tentang Pengembangan Video Tutorial Sistem Informasi Keluarga pada Pendidikan dan Pelatihan (Diklat) Perwakilan BKKBN Provinsi Sumatera Selatan, dapat disarankan beberapa hal sebagai berikut ini. Kepada peserta diklat, disarankan untuk menggunakan media video tutorial ini sebagai salah satu sumber belajar diklat untuk meningkatkan pengetahuan dan kompetensi teknis sebagai Penyuluh KB dalam pemutakhiran basis data keluarga di wilayah binaannya masing-masing.

Kepada fasilitator, disarankan untuk menggunakan media video tutorial ini sebagai salah satu referensi atau alternatif guna meningkatkan produktivitas pembelajaran diklat, sehingga peserta diklat termotivasi dalam mempelajari materi yang disampaikan.

Diklat Perwakilan BKKBN Provinsi Sumatera Selatan sebaiknya mengembangkan dan memanfaatkan media video tutorial untuk mata diklat yang lain sehingga tersedia banyak alternatif media pembelajaran yang dapat dimanfaatkan, baik oleh peserta pelatihan maupun fasilitator.

Para peneliti lain dapat mengembangkan media video tutorial dengan materi yang lain, lebih interaktif dengan menggunakan software terkini dan yang dapat diakses melalui smartphone atau gadget yang dimiliki Penyuluh KB sehingga sumber belajar diklat tersedia secara digital dan dapat diakses secara cepat. 


\section{PUSTAKA ACUAN}

\section{Buku}

Abdulhak, I., \& Darmawan, D. (2015). Teknologi Pendidikan. (A. Kamsyach, Ed.) (2nd ed.). Bandung: PT. Remaja Rosda Karya.

Alessi, S. M., \& Trollip, S. P. (2001). Tutorials in Multimedia for Learning: Methods and Development.

Anidi. (2017). Evaluasi Program Pembelajaran (1st ed.). Yogyakarta: Parama Publishing.

Arikunto, S. (2014). Prosedur Penelitian: Suatu Pendekatan Praktik (15th ed.). Jakarta: Rineka Cipta.

Arsyad, A. (2015). Media Pembelajaran (18th ed.). Jakarta: PT. Rajagrafindo Persada.

Basri, H., \& Rusdiana. (2015). Manajemen Pendidikan dan Pelatihan. (B. Saebani, Ed.) (1st ed.). Bandung.

Daryanto, \& Tarno, H. (2017). Pendidikan Orang Dewasa (POD) (1st ed.). Yogyakarta: Penerbit Gava Media.

Miarso, Y. (2015). Menyemai Benih Teknologi Pendidikan (2nd ed.). Jakarta: Prenadamedia Group.

Munir. (2017). Pembelajaran Digital. (Ruswandi, R. Firly, \&A. S. Surur, Eds.) (1st ed.). Bandung: Alfabeta.

Prawiradilaga, Dwi, S. (2014). Wawasan Teknologi Pendidikan (2nd ed.). Jakarta: Kencana Prenada Media Group.

Pribadi, B. A. (2017). Media dan Teknologi dalam Pembelajaran (1st ed.). Jakarta: Kencana.

Riduwan. (2015). Belajar Mudah Penelitian untuk Guru-karyawan dan Peneliti Pemula (10th ed.). Bandung: Alvabeta.

Ghufron, M. N., \& Rini Risnawati, S. (2014). Gaya Belajar: Kajian Teoritik (2nd ed.). Yogyakarta: Pustaka Pelajar.

Rusman. (2013). Belajar dan Pembelajaran Berbasis Komputer: Mengembangkan Profesionalisme Guru Abad 21 (2nd ed.). Bandung: Alfabeta.

Sanjaya, W. (2016). Strategi Pembelajaran Berorientasi Standar Proses Pendidikan (12th ed.). Jakarta: Kencana Prenada Media Group.

Setyosari, P. (2016). Metode Penelitian Pendidikan dan Pengembangan (4th ed.). Jakarta: Prenadamedia Group.
Sugiyono. (2017). Metode Penelitian \& Pengembangan/: Research and Development. (S. Y. Suryandari, Ed.) (3rd ed.). Bandung: Alfabeta.

Suprijanto. (2012). Pendidikan Orang Dewasa: dari Teori Hingga Aplikasi (IV). Jakarta: Bumi Aksara.

Suryani, N., Setiawan, A., \& Putria, A. (2018). Media Pembelajaran Inovatif dan Pengembangannya. (P. Latifah, Ed.) (pertama). Bandung: PT. Remaja Rosda Karya.

Suyono, \& Haryanto. (2016). Belajar dan Pembelajaran: Teori dan Konsep Dasar (6th ed.). Bandung: PT. Remaja Rosda Karya.

Tegeh, I. M., Jampel, I. N., \& Pudjawan, K. (2014). Model Penelitian Pengembangan (Pertama). Yogyakarta: Graha IImu.

Zainiyati, Husniyatus, S. (2017). Pengembangan Media Pembelajaran Berbasis ICT: Konsep dan Aplikasi pada Pembelajaran Pendidikan Agama Islam. (R. Al-Hanna, Ed.) (1st ed.). Jakarta: Kencana.

\section{Jurnal/Prosiding/Disertasi/Tesis/Skripsi}

Azmy, A. (2015). Pengembangan Kompetensi Sumber Daya Manusia untuk Mencapai Career Ready Professional di Universitas Tanri Abeng. Binus Business Review, 6 (2), 220232. Retrieved from https://doaj.org/article/ 1691c98e93254ffb91e2ecdb790fd1a0 (diunduh 27 Mei 2019).

DeVaney, T. A. (2009). Impact Video Tutorial in an Online Educational Statistica Course. MERLOT Jurnal of Online Learning and Teaching, 5, 600-608. (diunduh 18 Mei 2019).

Fahrurozi, S. K. (2017). The Development of Video Learning to Deliver a Basic Algorithm Learning. Indonesian Journal of Informatics Education, 1 (2), 49-56. (diunduh 18 April 2019).

Haryanto. (2015). Kajian Konseptual Media Pembelajaran. Jurnal Pendidikan, 3 (4), 3240. Retrieved from http://staffnew.uny.ac.id/ upload/131656343/penelitian/KAJIAN +KONSEPTUAL+MEDIA+ PEMBELAJARAN.pdf (diunduh: 10 Mei 2019).

Kurniawan, U. K., Pratomo, H., \& Bachtiar, A. (2010). Kinerja Penyuluhan Keluarga Berencana di Indonesia: Pedoman Pengujian 
Efektivitas Kinerja pada Era Desentralisasi. Kesmas: Jurnal Kesehatan Masyarakat Nasional, 5(1), 3-8. Retrieved from http:// jurnalkesmas.ui.ac.id/index.php/kesmas/ article/view/155. (diunduh :12 April 2019).

Lestari, S. (2014). Pengembangan Video Tutorial untuk Peningkatan Kompetensi Pedagogik Guru PAUD. Jurnal Teknodik Pustekom Kemdikbud, 18, 315-325. https://doi.org/http:/ /dx.doi.org/10.32550/teknodik.v0i0.137 (diunduh: 12 April 2019).

Maiyena, S., \& Haris, V. (2017). Praktikalitas Video Tutorial pada Matakuliah Eksperimen Fisika untuk Meningkatkan Keterampilan Proses Sains Mahasiswa. Jurnal IImiah Pendidikan Fisika Al-Biruni, 6(1), 75. https://doi.org/ 10.24042/jpifalbiruni.v6i1.647 (diunduh 15 April 2019).

Marpaung, B. J. R. (2014). Pengaruh Strategi Pembelajaran dan Gaya Belajar. Pengaruh Strategi Pembelajaran dan Gaya Belajar terhadap Hasil Belajar Pendidikan Kewarganegaraan, 7 (STRATEGI PEMBELAJARAN), 25-34. (diunduh 12 April 2019).

Martin, P. A. (2016). Tutorial Video Use by Senior Undergraduate Electrical Engineering Students. Australasian Journal of Engineering Education, 21(1), 39-47. https://doi.org/ 10.1080/22054952.2016.1259027 (diunduh 8 April 2019).

Nurseto, T. (2011). Membuat Media Pembelajaran yang Menarik - Tejo Nurseto. Ekonomi dan Pendidikan, 8, 19-35. (diunduh 21 Februari 2019).

Pipit Kiswieantoro, S. Kom. (2017). Tutorial Multimedia Pembelajaran (pp. 1-5). Bandung: Pusat Penelitian dan Pengembangan Pendidikan PPPK Petra. Retrieved from http:/ /tutorial.pppkpetra.or.id/etutor/camtasia/ camtasia.pdf (diunduh 12 April 2019).
Riki Rahmad. (2018). Pengembangan Media Pembelajaran Video Tutorial Menggunakan Camtasia Studio 8.5 pada Matakuliah Sistem Informasi Geografi (SIG). Jurnal IImiah Pendidikan dan Pembelajaran PPs Universitas Pendidikan Ganesha, 2 Nomor 1, 97-110. https://doi.org/http://dx.doi.org/ 10.23887/jipp.v2i1.13040 (diunduh 21 Maret 2019).

Van den Akker, J. (1999). Principles and Methods of Development Research. In Design Approaches and Tools in Education and Training (pp. 1-14). https://doi.org/10.1007/ 978-94-011-4255-7 (diunduh: 29 Mei 2019).

Van der Meij, H. (2014). Developing and Testing a Video Tutorial for Software Training. Technical Communication, 61(2), 110-122. Retrieved from http://www.ingentaconnect.com/content/ stc/tc/2014/00000061/00000002/art00004 (diunduh: 4 Maret 2019)

\section{Lain-Lain}

BKKBN. (2015). Rencana Strategis Badan Kependudukan dan Keluarga Berencana Nasional. Bkkbn, 1-43.

BKKBN. (2016). Analisis Data Kependudukan dan KB Hasil Susenas 2015. Rapat Koordinasi Nasional BKKBN, Jakarta, M, 1-8.

BKKBN. (2017). Peraturan Kepala BKKBN Nomor 2 Tahun 2017 Tentang Standar Kompetensi Penyuluh Keluarga Berencana. Jakarta: BKKBN.

DITBINLAP. (2017). Laporan Hasil Sertifikasi Penyuluh Keluarga Berencana Badan Kependudukan dan Keluarga Berencana Nasional. Jakata.

Kemendikbud. (2016). Kementerian Pendidikan dan Kebudayaan, Republik Indonesia.

Kemenpan. (2018). Jabatan Fungsional Penyuluh KB. Peraturan Menteri Pendayagunaan Aparatur Negara dan Reformasi Birokrasi Nomor 21 Tahun 2018 Tentang Jabatan Fungsional Penyuluh KB. Jakarta: Kemenpan dan RB Republik Indonesia 